\title{
MODELLING DUNE EROSION, OVERWASH AND BREACHING AT FIRE ISLAND (NY) DURING HURRICANE SANDY
}

\author{
P. LODEWIJK M. DE VET ${ }^{1,2,3}$, ROBERT T. MCCALL ${ }^{2}$, JOOST P. DEN BIEMAN ${ }^{2}$, \\ MARCEL J.F. STIVE ${ }^{1}$, MAARTEN VAN ORMONDT ${ }^{2}$
}

1. Department of Hydraulic Engineering, Delft University of Technology, Stevinweg 1, Delft, 2628CN, The Netherlands.P.L.M.deVet@tudelft.nl,M.J.F.Stive@tudelft.nl.

2. Deltares, Boussinesqweg 1, Delft, 2629HV, Postbus 177, 2600MH, The Netherlands. Robert.McCall@deltares.nl, Joost.denBieman@deltares.nl, Maarten.VanOrmondt@deltares.nl.

3. Department of Civil \& Environmental Engineering, National University of Singapore, 1 Engineering Drive 2, Singapore, 117576, Singapore.

\begin{abstract}
In 2012, Hurricane Sandy caused a breach at Fire Island (NY, USA), near Pelican Island. This paper aims at modelling dune erosion, overwash and breaching processes that occured during the hurricane event at this stretch of coast with the numerical model XBeach. By using the default settings, the erosion rates are substantially overestimated, which was also concluded in several previous case studies. If the discretization of bed roughness along with wave skewness and asymmetry are improved in the model, XBeach is capable of simulating the various morphological changes within the chosen model domain.
\end{abstract}

\section{Introduction}

In late October 2012, Hurricane Sandy caused substantial morphological changes along the coast of New York, due to storm surge and waves. Fire Island (NY, USA) was heavily impacted during this event, evidenced by the formation of breach channels, large-scale washover and destruction of houses and infrastructure. In this paper, we investigate and improve the capacity of a process-based 2DH numerical model (XBeach; Roelvink et al., 2009) to hindcast breaching, overwash and dune erosion (e.g., Sallenger, 2000) along a 2 $\mathrm{km}$ stretch of the Fire Island coastline, see Figure 1. By means of improving the model, more robust safety measures can be designed in future projects.

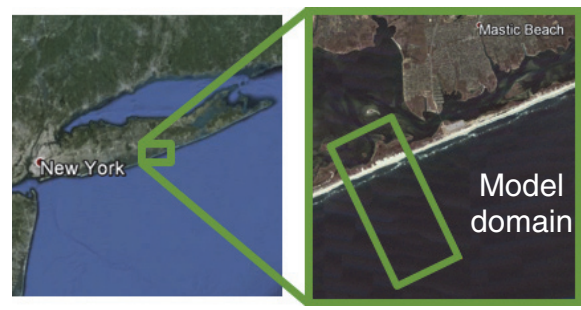

Fig. 1. Location model domain on satellite imagery; source: Google Earth. 
Figure 2 presents an overview of the morphological changes that were caused by the hurricane event. LIDAR data show that various storm processes are present in the considered $2 \mathrm{~km}$ stretch of coast: overwash from $y=0 \mathrm{~m}$ to $y=1100 \mathrm{~m}$ and around $y=1600 \mathrm{~m}$ (according to the coordinate system of Figure 2), breaching around $y=1100 \mathrm{~m}$ and dune erosion by collision of waves from $y=$ $1400 \mathrm{~m}$ to $y=2150 \mathrm{~m}$. In the years after Hurricane Sandy, the breach channel evolved from a post-storm width of roughly $50 \mathrm{~m}$ up to more than $300 \mathrm{~m}$ at present (USGS, 2014). This paper focuses purely on the formation of the breach during the hurricane event.

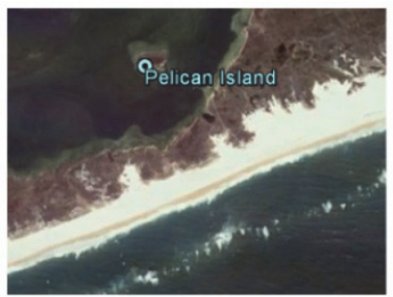

Pre-Sandy LIDAR data

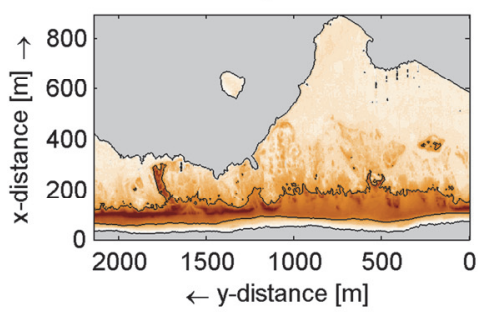

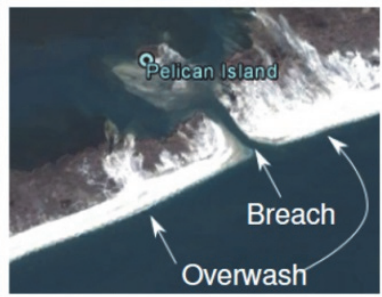

Post-Sandy LIDAR data

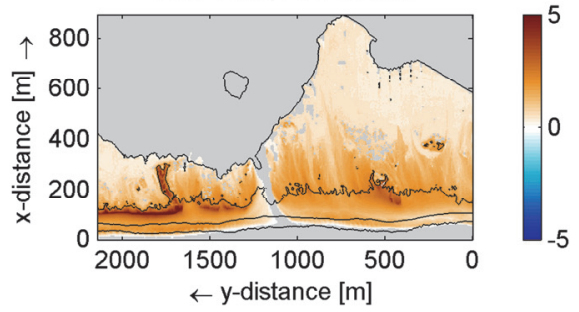

Fig. 2. Top figures: aerial photo prior to (left; July $3^{\text {rd }}, 2012$ ) and after (right; November $4^{\text {th }}, 2012$ ) the hurricane; source: Google Earth. Bottom figures: pre-Sandy (left, January 20 ${ }^{\text {th }}, 2012$ ) and postSandy (right, November $\left.5^{\text {th }}, 2012\right)$ LIDAR data; source: USGS (2012a). Reference level: NAVD88.

In various previous cases (cf., De Vet, 2014), XBeach overestimates the erosion rates if the model is applied under overwash and breaching conditions. McCall et al. (2010) introduced a sediment transport limiter to overcome the issue, but this is shown to hinder the occurrence of breaching and it is hence not a desired solution (De Vet, 2014). In this paper, an alternative approach is applied to achieve more realistic model predictions.

This study builds on previous research by implementing improved descriptions of bed roughness, wave shape and sediment transport in XBeach to overcome its current limitations under overwash and breaching conditions. The model is applied in this research to simulate the formation of a breach, as well as washover fans and dune erosion along the Fire Island coast. 


\section{Model Setup}

The offshore boundary of the XBeach model is located at a depth of $25 \mathrm{~m}$ and the opposite boundary is located in the back barrier bay. The bathymetry of the model is generated by merging various datasets: LIDAR data on top of the barrier island (USGS, 2012a), the Coastal Relief Model below mean sea level (NOAA, 2014) and LARC data for representing the breaker bar (USGS, personal communication, 2014). De Vet (2014) presents all the considerations regarding the merging process. The bathymetry is visualized in Figure 3. The model contains 357,738 grid cells, including a shadow zone of 45 degrees to cover oblique waves, having a minimal resolution of $\Delta x=2 \mathrm{~m}$ and $\Delta y=5 \mathrm{~m}$ at the barrier island, which increases smoothly to the offshore boundary. A morphological acceleration factor of 10 is applied, the same value as used by McCall et al. (2010), to reduce the computing time.

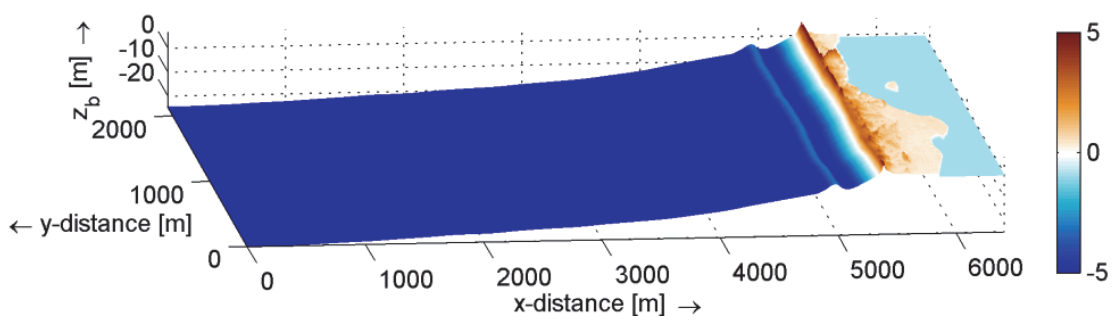

Fig. 3. Overview of the bathymetry of the model. Reference level: NAVD88.

Figure 4 presents the hydrodynamics imposed on the offshore and bay boundary of the XBeach model, covering the peak of the storm within the studied period of 48 hours, from the beginning of October $29^{\text {th }}$ till the end of October $31^{\text {st }}$.
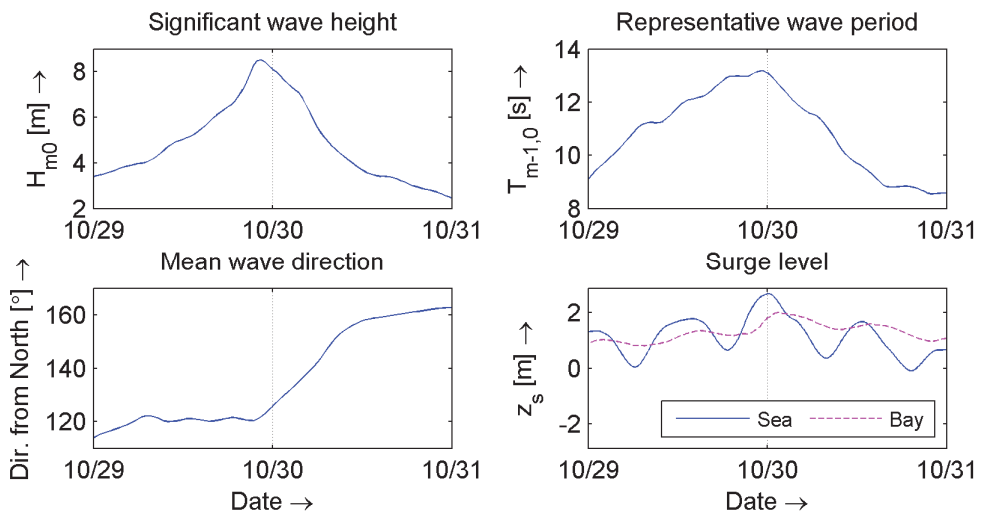

Fig. 4. Boundary conditions, the wave and surge level data at sea are obtained by a nesting procedure in a Delft3D model, the surge levels in the bay are measured by the USGS (2014b). Reference level: NAVD88. 
The surge level in the bay is based on nearby measurement data (USGS, 2014b). The wave conditions and surge level time series at the offshore boundary of the XBeach model were derived from a large-scale Delft3D model of Hurricane Sandy (Van Ormondt, personal communication, 2014). See De Vet (2014) for a validation of the Delft3D model results against measurement data.

A median grain size of $400 \mu \mathrm{m}$ is considered for the whole model domain, based on measurements taken in three locations close to the study site (USGS, personal communication, 2014).

The Manning roughness formulation is introduced as the non-depth dependent Chézy formulation (default value of $55 \mathrm{~m}^{0.5} \mathrm{~s}^{-1}$ ) is thought to be less realistic for large depth differences. Since some vegetation is present on top of the barrier island, the bed roughness is locally increased to reduce the flow velocities at these locations to account for this vegetation. A Manning value of 0.04 (Chow, 1959 ) is applied in the vegetated regions (determined by satellite imagery), a value of 0.02 is used elsewhere.

Furthermore, calibration is performed on the wave skewness and asymmetry parameter of the XBeach model. XBeach considers the wave energy of short waves as averaged over their length, and hence does not simulate the wave shape. A discretization of the wave skewness and asymmetry was introduced by Van Thiel de Vries (2009), to affect the sediment advection velocity. In this discretization, the sediment advection velocity $\left(u_{A}\right)$ is approximated by a function of a wave skewness parameter $\left(S_{k}\right)$, a wave asymmetry parameter $\left(A_{s}\right)$, the root mean square velocity $\left(u_{r m s}\right)$ and a calibration factor $\left(f_{u A}\right)$ :

$$
u_{A}=\left(S_{k}-A_{s}\right) u_{r m s} f_{u_{A}}
$$

By default, a value of 0.1 is used in XBeach for this calibration factor. In our study a value of 0.2 is considered, as it results in much more realistic results.

\section{Analysis of the Model Results}

In order to stress the importance of adjusting the bed roughness and the wave skewness and asymmetry parameters in XBeach, the model predictions without such adjustments and without numerical sediment transport limiters (e.g., McCall et al, 2010) are presented in Figure 5. By using the default XBeach parameter settings, the whole barrier island vanishes during the storm. 

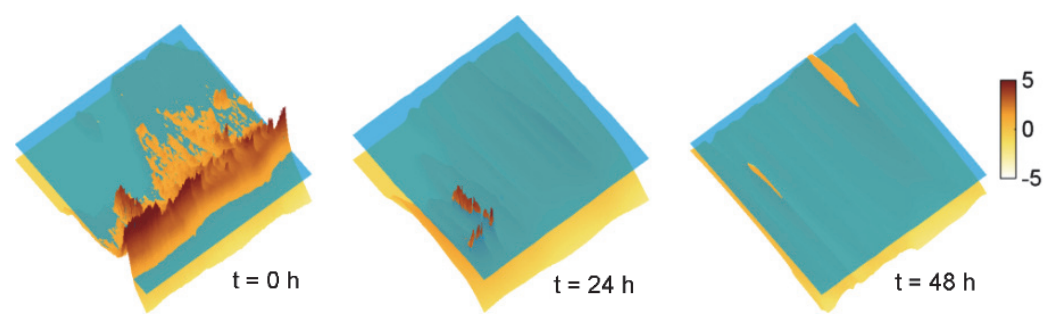

Fig. 5. Model results without adjustments and numerical sediment transport limiters. Reference level: NAVD88.

\section{Results with the Improved Model}

From now on, the modifications of the bed roughness parameter along with the wave skewness and asymmetry calibration parameter will be applied, as discussed in the model setup. Figure 6 presents a comparison of the model results to the LIDAR data measured four days after the hurricane event (USGS, 2012a). A very good agreement is achieved in the dune crest region (bed level above NAVD+2 m; Brier Skill Score in the order of 0.8).

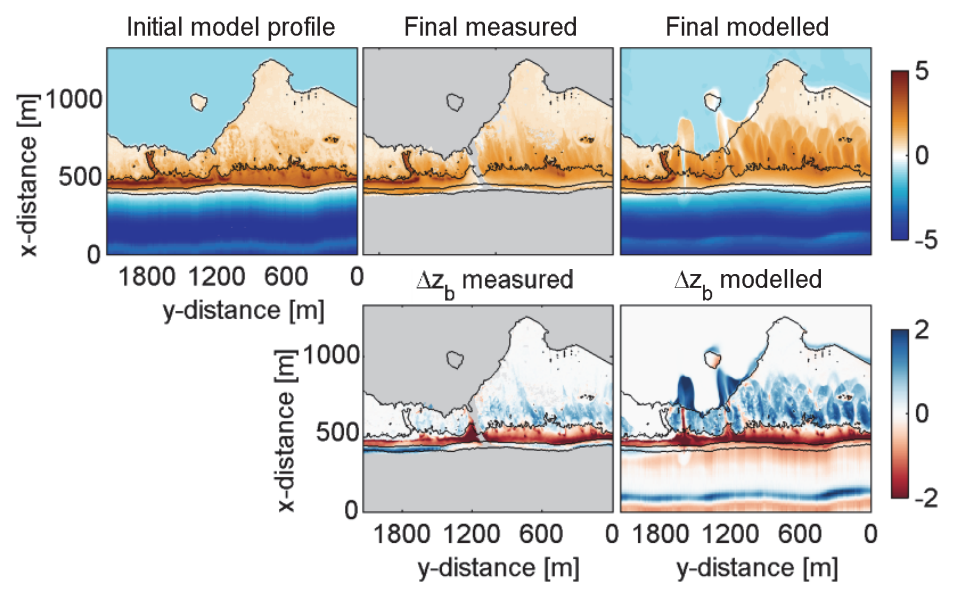

Fig. 6. Various bed level overviews with the initial model bathymetry, measurement data (USGS, 2012a) and model results. The black depth contours are provided at an elevation of 0 and $2 \mathrm{~m}$ relative to NAVD88 of the initial bed level profile. Areas without data are marked grey.

Some differences are observed if the model results are compared to the measurements. Firstly, it is found difficult to model the alongshore location of the breach correctly. Figure 6 shows that the breach is modelled at $y=1600 \mathrm{~m}$, whereas it appeared at $y=1100 \mathrm{~m}$ in reality. Secondly, the location of overwash deposits, behind the dune crests, is not entirely correct. The description of these features can be improved by further model calibration, but that is not the focus of this research. 
Modelled and measured cross-sections are provided in Figure 7. Besides the measured data and the model results with the improved description of the bed roughness and the wave skewness and asymmetry, the model results with the separate model improvements are also provided. From this, it can be deduced that wave skewness and asymmetry is mainly important for the region with pure dune erosion (e.g. the cross-section at $y=2000 \mathrm{~m}$ ) and that bed roughness is mainly important for overwash conditions (e.g. at $y=500 \mathrm{~m}$ ). As dune erosion could evolve in overwash if the dunes are lowered sufficiently, there are also areas in which both are important (e.g. at $y=1500 \mathrm{~m})$.
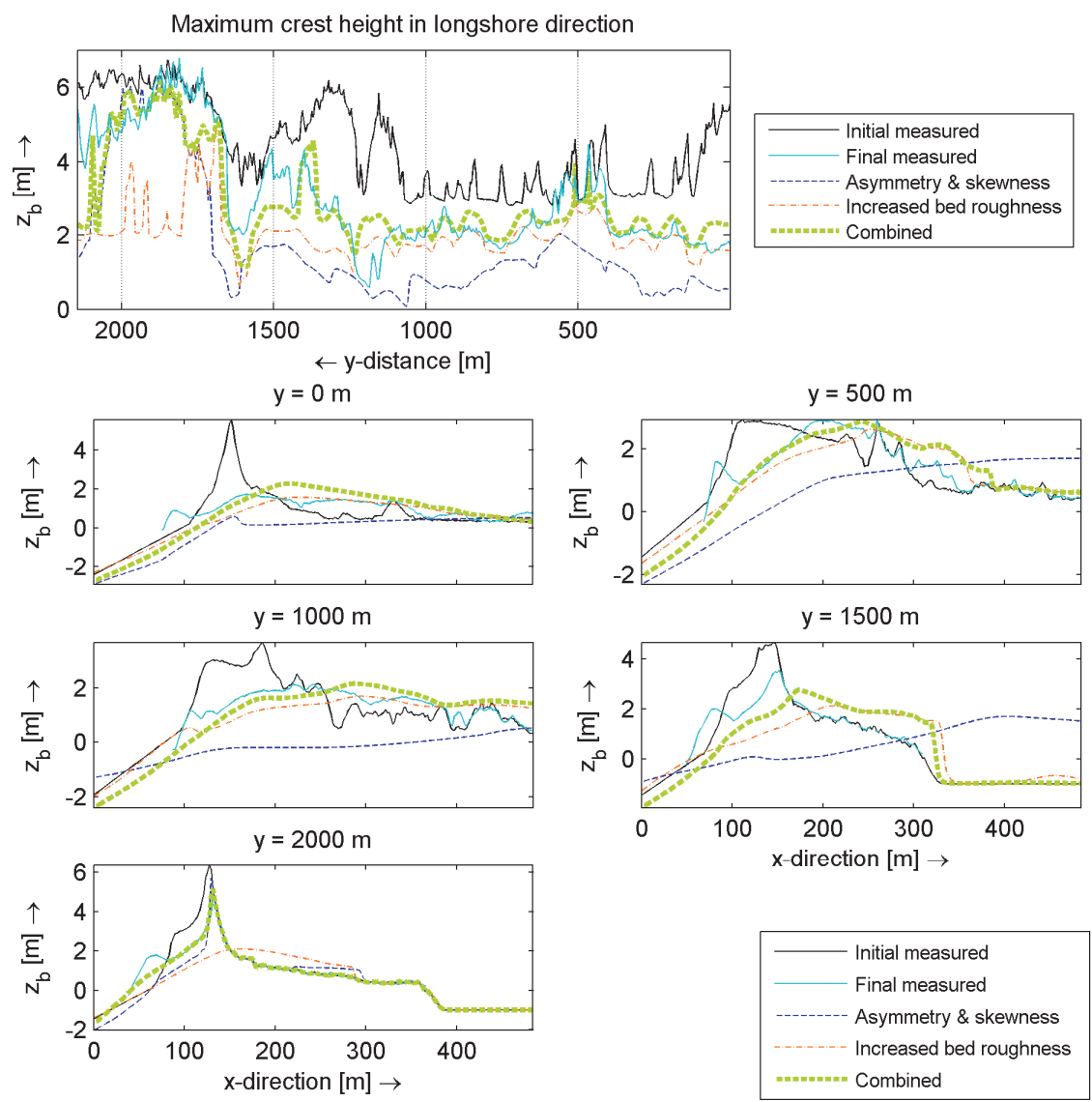

Fig. 7. Some cross-sections in longshore and cross-shore direction. The lines represent the initial bathymetry as visualised in Figure 3, the final measured profile (LIDAR data) and the model results with respectively the asymmetry and skewness improved, the representation of vegetation by a local increased bed roughness and both improvements combined. Reference level: NAVD88. 


\section{The Breach: Location and Evolution in Time}

As discussed before, the breach is not modelled at the right location. Still, the evolution of the breach channel in the model provides interesting insights. In order to study the evolution of the breach channel in more detail, the focus will be on some points in the successful (A, B and C) and unsuccessful (D, E and F) breach location in the model, see Figure 8 for the locations. The unsuccessful breach location is analysed at the position where the breach developed in reality.
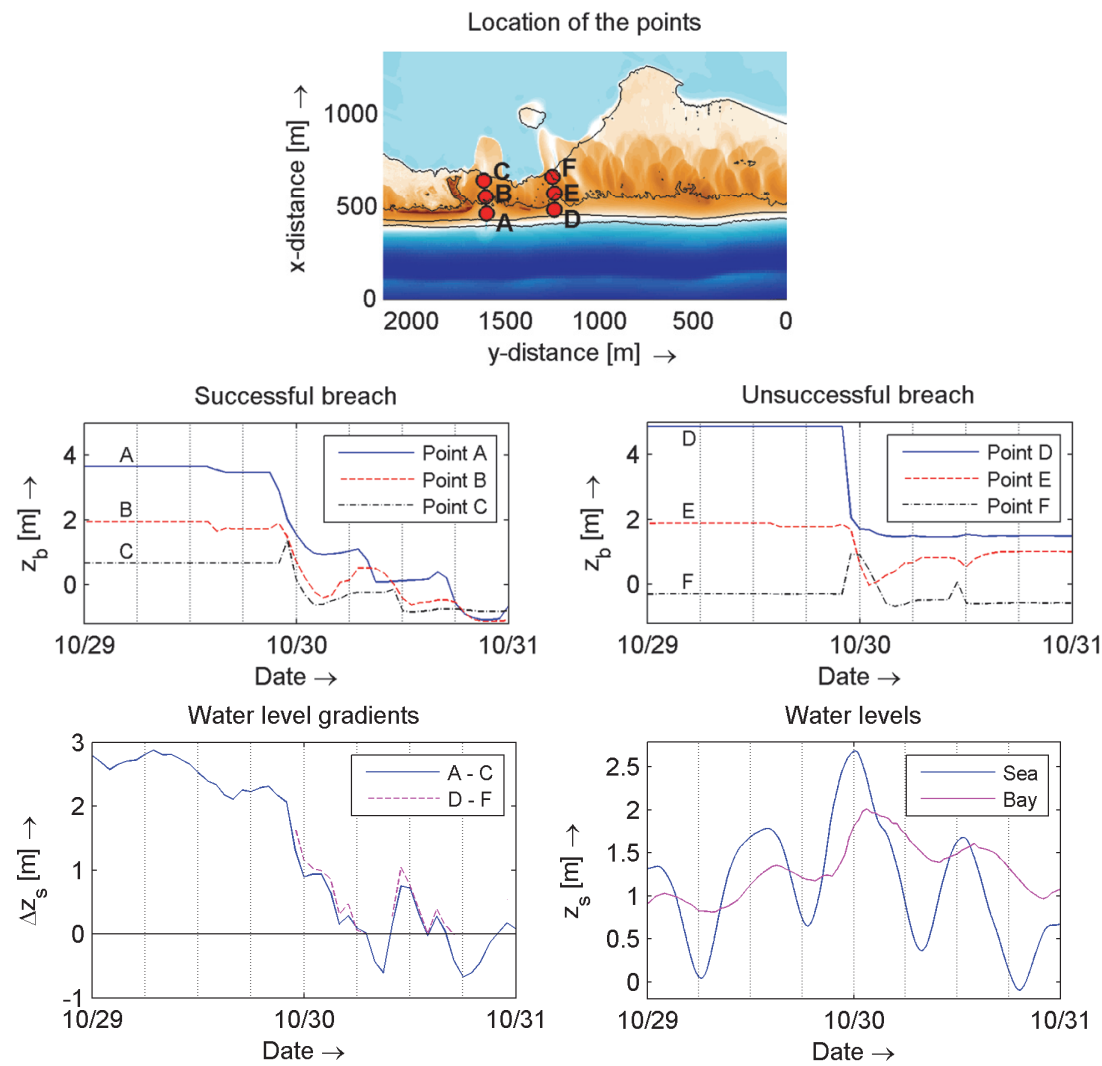

Fig. 8. Locations of the observed points in the successful (points A, B and C) and unsuccessful (points D, E and F) breach (top figure). Time series are provided for the modelled bed level changes (middle figures) and water level gradients (bottom left figure) at these points, together with the water levels imposed to the model (bottom right figure). Reference level: NAVD88.

Figure 8 shows the time series of the bed levels and the water level gradients in points A-F, together with the water levels at the boundaries. Initially, the morphology evolves similarly at both locations. As the storm surge reaches its 
maximum, the erosion velocities substantially increase and the dune tops erode. Just after the storm peak, important differences arise. The highest point of the unsuccessful breach (point D) remains at an almost constant elevation of about NAVD+1.8 m. Conversely, the highest point of the successful breach reaches an elevation of only NAVD+1.0 m. As this is lower than the local water level during the remaining modelled period, the breaching process continues once the local water level gradient increases again. The change in sign of the local water level gradients is interesting to notice; at some moments during the storm the velocity is directed from the bay towards the sea.

\section{Discussion}

A sensitivity analysis has shown that an increased bed roughness in the XBeach model is mainly important to obtain reasonable results in the overwash regime $(\mathrm{y}<1000 \mathrm{~m})$. The collision regime $(\mathrm{y}>1600 \mathrm{~m})$ is not substantially affected by this roughness increase, while a proper description of wave skewness and asymmetry is found to be of more importance in this regime. There is a need for more advanced bed roughness formulations, which should be capable of representing reduced bed roughness after substantial erosion takes place and the breach channel is smoothed by large flow velocities. However, improvements implemented in this paper already lead to very reasonable predictions.

It is shown that the modelling of the breaching process is a sensitive process. The modelled location of the breach differs from the location found in the observed data. At the real breaching location, the dunes did not lower enough to continue the breaching process in the model. A slight increase of the storm surge or wave forcing could be just enough to pass the erosion threshold of the dunes and with that to result in a successful breaching process. There could be many reasons why a breach is modelled at a location where it did not breach in reality, e.g. the soil could locally be less erodible. Although the breach is not modelled at the correct location, insights in the breaching process and its sensitivity to the model parameters are achieved. The storm surge at the peak of the storm causes an initial perturbation in the dunes. Under a continuous (but not constant) water level gradient, the erosion process continues for days (and even years as observed on satellite imagery) after the storm.

\section{Conclusion}

The work presented in this paper shows the applicability of a $2 \mathrm{DH}$ processbased model to simulate dune erosion, overwash and breaching on a barrier island during a hurricane event. The model discussed in this paper constitutes an improvement over previous modelling attempts, since no numerical limiters are applied to reduce washover transport, but rather a physics-based approach is 
used to better describe the conditions on the barrier island during the storm. The results of the model simulations show that correct approximation of the bed roughness and wave skewness and asymmetry are of importance for modelling the overwash and collision regime, respectively. Further research into the schematisation of these factors is recommended.

\section{Acknowledgements}

This research was part of a Master of Sience graduation thesis conducted at Deltares (The Netherlands). The authors thank Paul Visser (Delft University of Technology), Arno Talmon (Delft University of Technology) and Yuan Jing (National University of Singapore) for being part of the graduation thesis committee and their input.

\section{References}

Chow, V. T. (1959). “Open-channel hydraulics,” McGraw-Hill Book Company.

De Vet, P. L. M. (2014). "Modelling sediment transport and morphology during overwash and breaching events," MSc thesis, Delft University of Technology, Delft.

McCall, R. T., van Thiel de Vries, J. S. M., Plant, N. G., van Dongeren, A. R., Roelvink, J. A., Thompson, D. M., and Reniers, A. J. H. M. (2010). "Twodimensional time dependent hurricane overwash and erosion modeling at Santa Rosa Island," Coastal Engineering, 57:668-683.

NOAA (2014). "National Geophysical Data Center, U.S. Coastal Relief Model," Volume 1. Retrieved July 5 ${ }^{\text {th }}$, 2014, from http://www.ngdc.noaa.gov/mgg/coastal/crm.html.

Roelvink, J. A., Reniers, A. J. H. M., van Dongeren, A. R., van Thiel de Vries, J. S. M., McCall, R. T. and Lescinski, J. (2009). "Modelling storm impacts on beaches, dunes and barrier islands," Coastal Engineering, 56(11-12):1133 1152 .

Sallenger, A. H. (2000). "Storm impact scale for barrier islands," Journal of Coastal Research, 16(3):890-895.

USGS (2012a). "Topographic LiDAR: northeast Atlantic coast," NOAA's Ocean Service, Coastal Services Center (CSC). 
USGS (2012b). "Hurricane Sandy Monitoring, Station: SSS-NY-SUF-026WL," U.S. Geological Survey. Retrieved July $5^{\text {th }}$, 2014, from: http://ga.water.usgs.gov/.

USGS (2014). "Evaluation of a barrier-island breach created by Hurricane Sandy at Fire Island National Seashore, N.Y.," U.S. Geological Survey. Retrieved December 15 ${ }^{\text {th }}$, 2014, from: http://ny.water.usgs.gov/projects/hurr_sandy_2012/index.html.

Van Thiel de Vries (2009). "Dune erosion during storm surges," PhD thesis, Delft University of Technology. 